\title{
COMPOSITION OF MINERAL PHASES OF THE GHIDIRIM DIATOMITE
} Vasile Rusu* $^{\text {a* }}$ Aliona Vrînceanu ${ }^{\mathrm{a}}$ and Igor Polevoi ${ }^{\mathrm{b}}$

\author{
anstitute of Chemistry of the Academy of Sciences of Moldova, Academiei str. 3, MD-2028 Chişinău, Republic of Moldova \\ ${ }^{b}$ State University of Moldova, Mateevici str. 60, MD 2009, Chişinău, Republic of Moldova \\ *E-mail:vrusumd@yahoo.com; Phone: 37322 739731,Fax: 37322739954
}

\begin{abstract}
Studies of the mineralogical composition of diatomite from the Ghidirim location of RM, as well as of the extracted clay phase are presented. The mineral phase of the diatomite contains a number of clay minerals, like montmorillonite (in a mixture with insignificant quantities of slightly chloritized montmorillonite), illite and kaolinite. Diatomite contains also non-clay components as fine-dispersed quartz and amorphous material, the more probable sources of which are opal, amorphous alumosilicates, aluminum and iron hydroxides. The applied procedure for separation of clay fractions by sizing settling in liquid media proves to be very useful, enabling possibilities for more accurate identification of the clay constituents of diatomic material. Procedure allows to separate very clean clay fraction especially rich in montmorillonite, which can be utilized itself as mineral adsorbent for practical purposes.
\end{abstract}

Keywords: diatomite, mineralogical composition.

\section{INTRODUCTION}

The Republic of Moldova is relatively rich in deposits of mineral adsorbents, including the diatomaceous earth, which possess appropriate physicochemical characteristics for usage in the technologies for clearing of juices, wines, vegetal oils, for a water treating, purification of waste waters etc. [1-6]. Significant deposits are localized along course of the Dniester, on the sector Naslavcea - Camenca. The properties of diatomites may vary over a wide range depending on the mineralogical, granulometrical, chemical composition and parameters of the porous structure. The diatomite from the Ghidirim location primarily is characterized by a macroporous structure allowing to be used basically in the processes of purification of systems containing components with large molecular sizes. Generally, depending on the mineralogical structure, diatomites can represent formations from well crystallized forms (christobalite) to quite amorphous forms (opal). Researcher's and practitioner's interests are concentrated actually on extension of the field of application of diatomites, as well as intensification of their usage efficiency through modification of the surface chemistry also the concentration of the diatomic phase by the elimination of impurities existing in the diatomic raw material. At the same time a common tendency is watched, particularly in the case when there is raised the problem for purification of diatomites from various impurities. More often, the question is mooted to cleanse the diatomic phase of all other phases, including clay minerals. In fact, the clay minerals which are present in the diatomic formations may be of a special interest for certain usages. Consequently, when the question is mooted to cleanse the diatomic formations the formulation should also include the proceeding of reutilization of the clay components.

Current work includes studies of the mineralogical composition of diatomite from the Ghidirim location of RM, as well as of the extracted clay phase, the furthermost purpose being synthesis of modified mineral adsorbents.

\section{RESULTS AND DISCUSSIONS}

\subsection{Mineral-composition of diatomite}

Figure 1 shows X-ray diffractograms of the Ghidirim diatomite, the integral sample containing all the characteristic constituents. Results demonstrate the presence of kaolinite and illite identified by the behavior of the basic reflexes of the samples before and after thermal treatment. Kaolinite is characterized by the presence of the basic reflexion (noncalcinated samples) localized at $7,1 \AA$, depending on the degree of crystallization [7]. This reflex remains practically unchanged after the calcinations at $350^{\circ} \mathrm{C}$, but disappears after calcinations at $550^{\circ} \mathrm{C}$. For the studied diatomite a reflex at $7,08 \AA$ is registered for non-calcinated samples, persisting after calcinations at $350^{\circ} \mathrm{C}$ and considerably decreasing in the intensity after calcinations at $550^{\circ} \mathrm{C}$. On its place a weak and diffuse reflex, asymmetric in the direction of low angles, is registered at about $6,97 \AA$. Thus, the results show the presence of kaolinite in the studied diatomite. At the same time the behavior of the respective reflex after calcinations at $550^{\circ} \mathrm{C}$ suggests the presence of some other clay components with special properties that will be discussed further.

Characteristic for illite is the presence of the basic reflex (non-calcinated samples) localized in the range of 9,9$10 \AA$ depending on the degree of crystallization [7]. This reflex remains essentially unchanged after calcinations at $350^{\circ} \mathrm{C}$ and $550^{\circ} \mathrm{C}$. The intensity of this reflex increases after heat treatment in case when the studied material contains such minerals as montmorillonite, vermiculite or chlorite, due to the shift of basic reflexions of these minerals towards $10 \AA$. The presence of illite in the studied diatomite is demonstrated by the presence of the $9,94 \AA$ reflex for non-calcinated samples, becoming much more intensive after calcinations at $550^{\circ} \mathrm{C}$. 


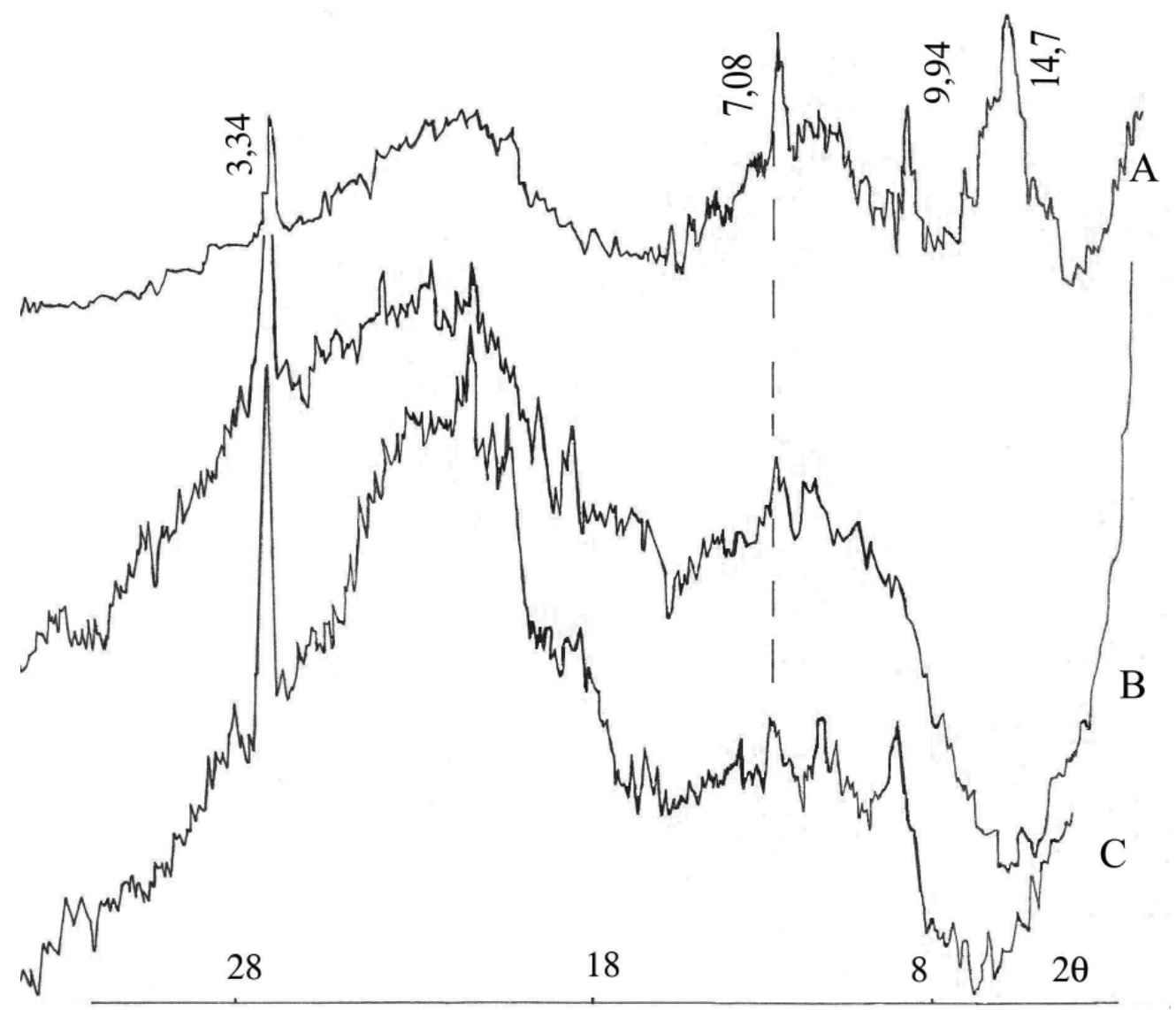

Fig. 1. X-ray diffractograms of the Ghidirim diatomite. Non-calcinated samples (A), after calcinations at $350^{\circ} \mathrm{C}(\mathrm{B})$ and $550^{\circ} \mathrm{C}(\mathrm{C})$.

After calcinations at $350^{\circ} \mathrm{C}$ the basic line on diffractograms becomes arched and very diffuse in the range of 10$6 \AA$, due to complex behavior of amorphous components (more probably, opal) which are present in diatomite material. Reflex of kaolinite $(7,1 \AA)$ as well as reflexions of some new phases $(7,69 \AA)$ are registered on the background of this

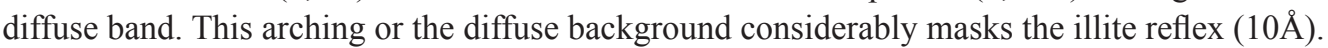

Identification of phases with reflexions in the range $>10 \AA$ is more complicated. The basic reflex in the range of $>10 \AA$ of the non-calcinated samples is registered at $14,7 \AA$, with a diffuse "branch" in the range of 16-16,6 . Calcinations at $350^{\circ} \mathrm{C}$ "cleans" the $>10 \AA$ range, however the behavior of the $9,97 \AA$ reflex cannot be followed due to diffuse background in this range. Better intensification of the $9,97 \AA$ reflex is noted after calcinations at $550^{\circ} \mathrm{C}$.

Certain peculiarities of behavior of the reflexions in the range $>10 \AA$ must be pointed especially, e.g. the presence of the $16-16,6 \AA$ "branch" for the non-calcinated samples, a strong decrease of the intensity of the main reflex $14,7 \AA$ and its shifting to $10 \AA$ after calcinations at $350^{\circ} \mathrm{C}$ (on the background of the diffuse arching in the $10-6 \AA$ range), and slight intensification of residual reflexions in the range $13-14 \AA$ after calcinations at $550^{\circ} \mathrm{C}$. Such behavior of phases in the range $>10 \AA$ suggests the presence of montmorillonite in a mixture with insignificant quantities of slightly chloritized montmorillonite [7]. The montmorillonite is identified by the presence of the main reflex $14,7 \AA$ and its contraction after

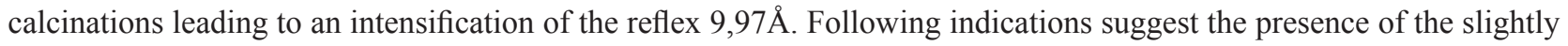
chloritized montmorillonite. When Al-, Fe-hydroxy complexes are present in the interlayer spacing of montmorillonite, the mineral looses its normal contraction capacity after thermal treatment due to formation of associations closely bound to crystal packages. These formations represent intermediate systems between veritable 2:1 minerals (with characteristic properties) and Al-, Fe-chlorite being "intermediate" or intergrade minerals. The mentioned behavior of the reflexions in the range $>10 \AA$ demonstrates that the "intermediate" mineral in the studied diatomite is poorly chloritized and refers to slightly chloritized montmorillonite with Al-, Fe-hydroxy complexes being "insular" distributed in the interlayer spacing [7].

Characteristic for the slightly chloritized montmorillonite is the decrease of the reflex at $14 \AA$ after calcinations, shifting after $350^{\circ} \mathrm{C}$ to smaller values or forming a diffuse band in the range of $12-14 \AA$. Sometimes calcinations at 500$600^{\circ} \mathrm{C}$ can produce an intensification of the reflex in the range of $12-14 \AA$, depending on degree of chloritization of such 
formations. The obtained results confirm the presence of slightly chloritized montmorillonite in the studied diatomite, which is indicated by the presence of the "branch" at $16-16,6 \AA$ for non-calcinated samples, strong decrease of the intensity of the main reflex at $14,7 \AA$ and its shift towards $10 \AA$ after calcinations at $350^{\circ} \mathrm{C}$ (on the background of the

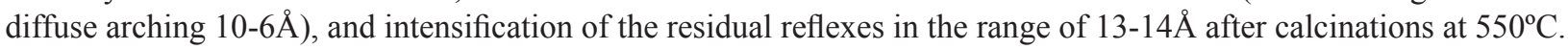

Besides of mentioned clay minerals the studied diatomite contains also certain amounts of non-clay components. Particularly, the presence of fine-dispersed quartz is registered being identified by the presence of the main reflex at $3,34 \AA$. Also, the presence of significant quantities of amorphous materials is registered being identified by arched

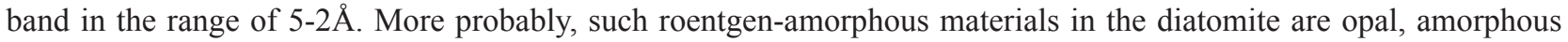
aluminum and iron compounds, e.g. amorphous alumosilicates, hydroxides, hydroxy-complexes etc. However, further investigations are needed to more exactly identify the possible components of the amorphous material.

As a whole, the mineral phase of the Ghidirim diatomite contains a number of clay minerals, like montmorillonite (in a mixture with insignificant quantities of slightly chloritized montmorillonite), illite and kaolinite. Diatomite contains also non-clay components as fine-dispersed quartz and amorphous material, the more probable sources of which are opal, amorphous alumosilicates, aluminum and iron hydroxides etc.

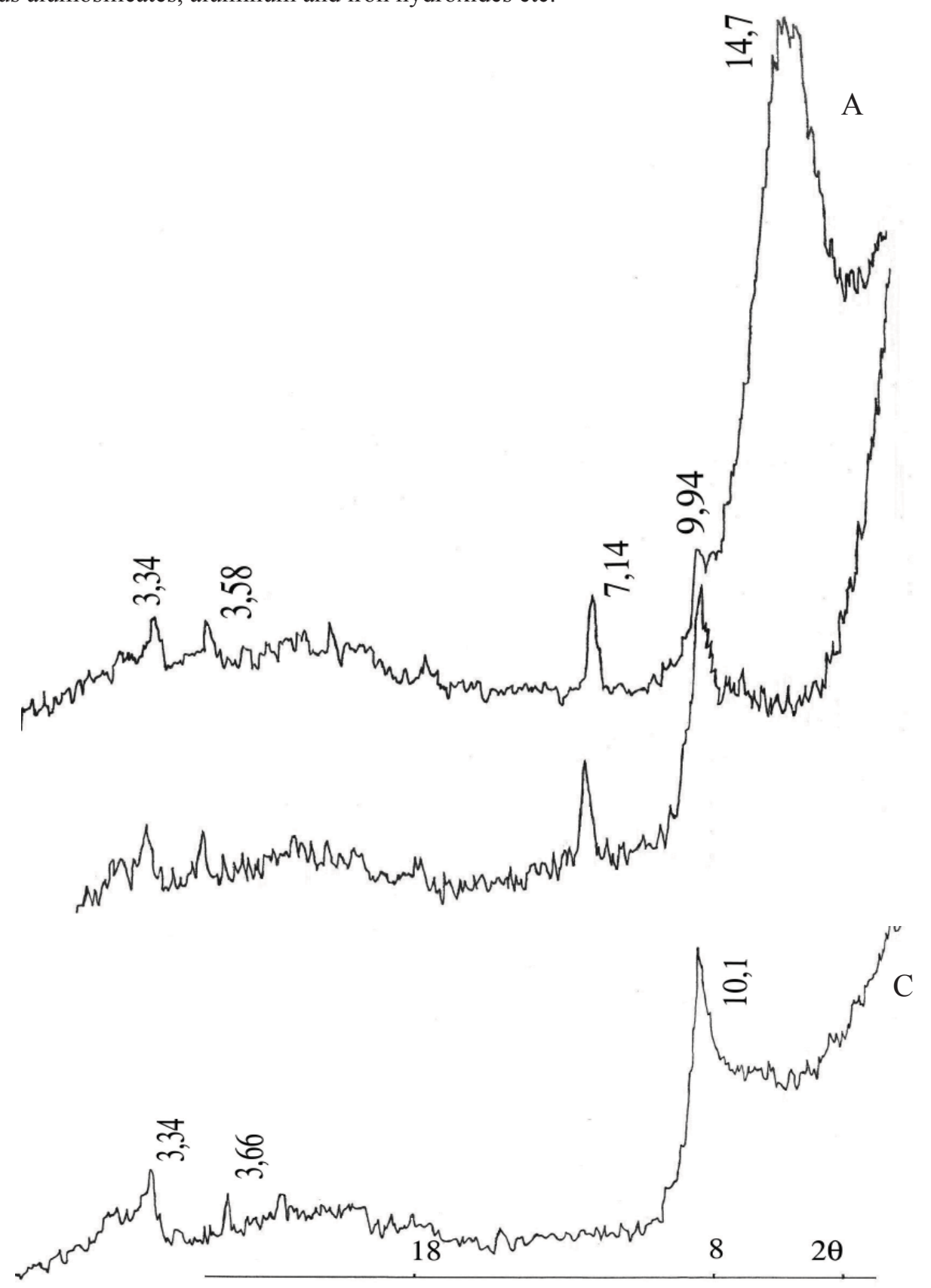

Fig. 2. X-ray diffractograms of the clay fractions extracted from the Ghidirim diatomite. The non-calcinated samples

(A), after calcinations at $350^{\circ} \mathrm{C}(\mathrm{B})$ and $550^{\circ} \mathrm{C}(\mathrm{C})$. 


\subsection{Extraction of the clay fraction from the diatomite}

Extraction of the clay minerals from the studied diatomite was performed using the method of sizing by settling in liquid media (distilled water) [7]. The procedure insures "mild" conditions for the extraction of clay constituents without their denaturing or destroying. For the extraction of different constituents from solid materials (soils, sediments, clay formations) are applied various chemical reagents (acids, bases, complexons etc.), however the degree of selectivity and effects on other components should be well-argued by individual investigations of each type of solid material [7]. Aqueous extraction applied in these studies are more easily to perform and, though sizing by settling in liquid media does not insure a complete extraction of all clay constituents from diatomite, such procedure, what is more importantly, does not alter natural chemical composition of clays. Fig. 2 shows diffractograms of the clay components extracted from the Ghidirim diatomite. Diffractograms of the integral diatomite, presented in figure 1, represents properly summary structure of the diatomic material, showing clay fraction on the background of the diatomic formation. Fig. 2 shows just the structure of the clay fraction separated from non-clay components, in consequence diffractograms are more "clean" showing distinctly reflexions of the clay minerals and their veraciously behavior on thermal treatment. The presence of montmorillonite, illite and kaolinit in separated clay fraction is uniquely demonstrated. Also, in this case the identification of the slightly chloritized montmorillonite is more veraciously proved by decreasing of the reflex in the range of $14 \AA$ after thermal treatment being shifted after $350^{\circ} \mathrm{C}$ to the smaller values in the form of diffuse bands in the range of $12-14 \AA$.

Though some quantities of fine-dispersed quartz also penetrate into the separated clay fraction, these quantities are matchless smaller compared to those which are contained in the initial diatomic material. It is very importantly that the separated clay fraction does not contain amorphous material extracted from the initial diatomic material.

Thus, the applied procedure of clay fraction separation by sizing settling in liquid media proves to be very useful enabling possibilities for more accurate identification of the clay constituents of diatomic material. Also, along with an accurate diagnostics of the clay minerals, it is very important that the applied procedure allows to separate very clean clay fraction especially rich in montmorillonite, which can be utilized itself as mineral adsorbent for practical purposes.

\section{EXPERIMENTAL PART}

The diatomite from the Ghidirim location of RM was used for investigations. The physical-chemical characteristics and parameters of the porous structure of this diatomite were described early [1]. Samples of diatomite containing all characteristic constituents (integral diatomic material) and separated clay fraction extracted by sizing settling in distilled water were studied. X-ray analysis was performed using the DRON-1 X-ray installation with CoK $\alpha$ radiation. There were used oriented preparations exposed to various thermal treatments in series (i) non-calcinated samples, (ii) samples after calcinations at $350^{\circ} \mathrm{C}$ and (iii) samples after calcinations at $550^{\circ} \mathrm{C}[7]$.

\section{CONCLUSIONS}

The performed analysis shows that the mineral phase of the Ghidirim diatomite contains a number of clay minerals, like montmorillonite (in a mixture with insignificant quantities of slightly chloritized montmorillonite), illite and kaolinite. The studied diatomite contains also non-clay components, some being well crystallized, for example fine dispersed quartz, as well as amorphous material, the more probable sources of which are opal, amorphous alumosilicates, aluminum and iron hydroxides.

The applied procedure for separation of clay fractions by sizing settling in liquid media proves to be very useful, enabling possibilities for more accurate identification of the clay constituents of diatomic material. Procedure allows to separate very clean clay fraction especially rich in montmorillonite, which can be utilized itself as mineral adsorbent for practical purposes.

\section{REFERENCES}

[1] Kerdivarenko, M.A. Moldavschie prirodnîe adsorbentî i tehnologhia ih primenenia. Kishinev: Cartea moldoveneasca, 1975, 190p. (rus.).

[2] Ropot, V.M.; Stratulat, G.V.; Sandu, M.A.; Lupashcu, F.G.; Rusu, V.I. i dr. Problemî cacestva, ispolyzovania i ohranî vodnîh resursov SSR Moldova. Kishinev: Stiința, 1991, 285 p. (rus.).

[3] Totok, G.T.; Rusu, V.I.; Ropot, V.M.; Bolotin, O.A. Recomendații na primenenie bentonitovîh glin MSSR dlea ocistchi prirodnîh vod. Utverjdenî Ministerstvom jilicyno-komunalynogo hozeaystva MSSR, ot 14.01.1986g. Kishinev: Stiința, 1986, 8p (rus.).

[4] Kerdivarenko, M.A.; Şeremet, N.V; Rusu, V.I. i dr. Izvestia Academii Nauk MSSR, seria biol. I him. nauk, 1990, No. 5, p.56-62 (rus.).

[5] Kerdivarenko, M.A.; Şeremet, N.V; Rusu, V.I. i dr. Izvestia Academii Nauk MSSR, seria biol. I him. nauk, 1991, No. 1, p.56-61 (rus.).

[6] Zelențov, V.; Datco, T.; Dvornicova, E. Proceedings of Intern. Conf. "Mediul şi Industria”, Bucureşti, 2005 (rom.).

[7] Rusu, V.; Lupaşcu, T. Chimia sedimentelor sistemelor acvatice. Proprietăți de suprafață. Modele fizico-chimice. Chişinău: IPE Elena VI, 2004, 272p. (rom.). 